US Army Corps

of Engineers ${ }_{\circledast}$

Engineer Research and

Development Center

\title{
Variation in Inhibitor Effects on qPCR Assays and Implications for eDNA Surveys
}

Richard F. Lance and Xin Guan

August 2021 
The U.S. Army Engineer Research and Development Center (ERDC) solves the nation's toughest engineering and environmental challenges. ERDC develops innovative solutions in civil and military engineering, geospatial sciences, water resources, and environmental sciences for the Army, the Department of Defense, civilian agencies, and our nation's public good. Find out more at www.erdc.usace.army.mil.

To search for other technical reports published by ERDC, visit the ERDC online library at https://erdclibrary.on.worldcat.org/discovery. 


\title{
Variation in Inhibitor Effects on qPCR Assays and Implications for eDNA Surveys
}

\author{
Richard F. Lance \\ Environmental Laboratory \\ U.S. Army Engineer Research and Development Center \\ 3909 Halls Ferry Road \\ Vicksburg, MS 39180 \\ Xin Guan \\ Bennett Aerospace \\ 3909 Halls Ferry Road \\ Vicksburg, MS 39180
}

Final report

Approved for public release; distribution is unlimited.

\author{
Prepared for U.S. Army Corps of Engineers \\ Washington, DC 20314 \\ Under U.S.EPA Great Lakes Restoration Initiative
}




\section{Preface}

This project was conducted for the U.S. Army Corps of Engineers (USACE) and was funded by the Great Lakes Restoration Initiative (GLRI), as administered by the U.S. Environmental Protection Agency, and overseen by the GLRI Asian Carp Coordinating Committee.

The work was performed by the Army's Engineer Research and Development Center, Environmental Laboratory (ERDC-EL). At the time of publication of this paper, the Deputy Director of ERDC-EL was Dr. Brandon Lafferty and the Director was Dr. Edmund J. Russo Jr.

This article was originally published in the Canadian Journal of Fish and Aquatic Science on 8 May 2019.

The Commander of ERDC was COL Teresa A. Schlosser and the Director was Dr. David W. Pittman.

DISCLAIMER: The contents of this report are not to be used for advertising, publication, or promotional purposes. Citation of trade names does not constitute an official endorsement or approval of the use of such commercial products. All product names and trademarks cited are the property of their respective owners. The findings of this report are not to be construed as an official Department of the Army position unless so designated by other authorized documents. 


\title{
Variation in inhibitor effects on qPCR assays and implications for eDNA surveys
}

\begin{abstract}
Aquatic environmental DNA (eDNA) surveys are sometimes impacted by polymerase chain reaction (PCR) inhibitors. We tested varying concentrations of different inhibitors (humic, phytic, and tannic acids; crude leaf extracts) for impacts on quantitative PCR (qPCR) assays designed for eDNA surveys of bighead and silver carp (Hypophthalmichthys nobilis and Hypophthalmichthys molitrix). We also tested for inhibition by high concentrations of exogenous DNA, hypothesizing that DNA from increasingly closely related species would be increasingly inhibitory. All tested inhibitors impacted qPCR, though only at very high concentrations - likely a function, in part, of having used an inhibitor-resistant qPCR solution. Closer phylogenetic relatedness resulted in inhibition at lower exogenous DNA concentrations, but not at relatively close phylogenetic scales. Inhibition was also influenced by the qPCR reporter dye used. Importantly, different qPCR assays responded differently to the same inhibitor concentrations. Implications of these results are that the inclusion of more than one assay for the same target taxa in an eDNA survey may be an important countermeasure against false negatives and that internal positive controls may not, in the absence of efforts to maximize inhibition compatibility, provide useful information about the inhibition of an eDNA assay.

Résumé : Les inhibiteurs de la réaction en chaîne par polymérase (RCP) ont parfois un impact sur les études reposant sur l'ADN environnemental $(\mathrm{ADNe})$ aquatique. Nous avons vérifié si différentes concentrations de différents inhibiteurs (acides humique, phytique et tannique et extraits bruts de feuilles) avaient une incidence sur des analyses quantitatives par RCP (RCPq) conçues pour des études d'ADNe de carpes à grosse tête et l'argentées (Hypophthalmichthys nobilis et Hypophthalmichthys molitrix). Nous avons également vérifié si de fortes concentrations d'ADN exogène avaient aussi un effet inhibant, postulant que de l'ADN d'espèces de plus en plus étroitement apparentées serait de plus en plus inhibant. Tous les inhibiteurs examinés avaient un impact sur la RCPq, mais seulement à de très fortes concentrations, probablement dû au fait, en partie, de l'utilisation d'une solution résistante aux inhibiteurs de la RCPq. Une parenté phylogénétique plus étroite se traduisait par une inhibition à de plus faibles concentrations d'ADN exogène, mais pas à des échelles phylogénétiques relativement proches. L'inhibition était aussi influencée par le colorant rapporteur utilisé pour la RCPq. Fait important, différentes analyses par RCPq répondaient différemment aux mêmes concentrations d'inhibiteurs. Ces résultats indiqueraient que l'inclusion de plus d'une analyse pour les mêmes taxons cibles dans les études reposant sur l'ADNe pourrait être une importante mesure pour éviter les faux négatifs, et que l'utilisation de témoins positifs internes, en l'absence d'efforts pour maximiser la compatibilité de l'inhibition, pourrait ne pas fournir d'information utile concernant l'inhibition dans une analyse d'ADNe. [Traduit par la Rédaction]
\end{abstract}

\section{Introduction}

Over the last several years, there has been a growing interest in the detection of plant and animal DNA in water samples (Ficetola et al. 2008; Dejean et al. 2012; Goldberg et al. 2011; Jerde et al. 2011; Fujiwara et al. 2016). The DNA obtained from these samples is generally termed "environmental DNA" or "eDNA". With typical eDNA sampling, free DNA, DNA-bearing particulates (e.g., clay particles; Goring and Bartholomew 1952), or DNA containing matter (e.g., intact mitochondria) and other undissolved matter are isolated from water samples by passing water through submicron or micron-scale filters or by centrifuging the material and decanting water away from the resulting pellet (Ficetola et al. 2008; Goldberg et al. 2011). Next, eDNA samples are processed through the following steps: (i) using one of many possible DNA extraction protocols to isolate the DNA into an aqueous solution (or elution), (ii) applying an aliquot of the elution to conventional endpoint polymerase chain reaction (PCR) or quantitative real-time PCR (qPCR) with taxa-specific primers (and hydrolysis probes for some variants of qPCR), (iii) viewing the PCR or qPCR results to see if expected DNA amplicons are apparent, and sometimes (iv) sequencing the PCR amplicon to verify that it corresponds to the targeted species' DNA. In some cases, PCR is used to enrich the eDNA sample for a subsequent next-generation sequencing assay (e.g., DNA metabarcoding)

One of the most commonly cited confounding factors in eDNA results is potential PCR inhibition (Goldberg et al. 2011; Jane et al. 2015; McKee et al. 2015b). PCR inhibition occurs when a constituent in a PCR reaction - usually an unwanted compound that persists in solution through DNA extraction and isolation interferes with PCR at a molecular level and either completely prevents the production of the target amplicon or substantially reduces the amount of amplicon that is produced (Opel et al. 2010). Such an effect is particularly worrisome for eDNA surveys, as intact target DNA is typically a very minor, partly degraded constituent of the overall environmental DNA sample. Because PCR inhibitors can be difficult to completely eliminate or ameliorate, many eDNA survey protocols call for internal positive PCR controls (IPCs). IPCs are composed of a DNA template and PCR primers for amplifying that template. In the case of hydrolysis probe qPCRs 
(e.g., TaqMan qPCR), the IPC will also include a short dual-labeled oligonucleotide (i.e., the probe) complimentary to a DNA sequence within the IPC amplicon. IPCs can be run in multiplex PCRs (or qPCRs) with the actual eDNA assay (Schmidt et al. 2013; Turner et al. 2014; Wilson et al. 2014) or as separate IPC-only PCRs (or qPCRs). A reaction is considered inhibited if there is a failure to either amplify the IPC or if an increase is observed in the qPCR Ct (cycle number at which amplification threshold surpasses the background fluorescence threshold) relative to that observed in known clean solutions (e.g., positive controls). This approach, however, assumes that PCR of the IPC will be impacted by inhibitors in the same manner as the eDNA assay. Other than exploring remedies to PCR inhibition (McKee et al. 2015a; Williams et al. 2017) and the somewhat standard employment of IPCs, there has been very little effort among eDNA practitioners to better understand the complexities and implications that different inhibitors bring to bear on eDNA practice (but see Stoeckle et al. 2017).

Fortunately, some information on PCR inhibition can be obtained from studies of forensic DNA, ancient DNA, water quality science, soil metagenomics, etc. (Wilson 1997; Sørensen et al. 2003; Albers et al. 2013). It is known that PCR inhibitors usually affect PCR through direct interaction with DNA or interference with the DNA polymerase and (or) other PCR reagents. There is a large variety of PCR inhibitory compounds that can be co-extracted with DNA. For example, tannic acid may bind magnesium, which is a co-factor affecting DNA polymerases, and thus inhibit polymerase activity (Opel et al. 2010). Humic acids interact with the template DNA and the polymerase, subsequently preventing the enzymatic reaction even at low concentrations (Sutlović et al. 2005, 2008; Opel et al. 2010). Recently, Stoeckle et al. (2017) identified humic substances as particularly problematic inhibitors for eDNA surveys. For qPCR methods utilizing double-stranded DNA-binding dyes (e.g., SYBR Green I), humic substances may quench dye fluorescence (Sidstedt et al. 2015). In the same study, hydrolysis probe qPCR (e.g., TaqMan qPCR) fluorescence was not quenched by humic substances. In both types of qPCR (DNA-binding dye and hydrolysis probe), assay results may be impacted when humic substances inhibit PCR efficiency. Schrader et al. (2012) list exogenous DNA as a potential qPCR inhibitor, though very high concentrations are required to achieve inhibition (Kainz 2000). Such a situation might arise in an eDNA survey when exogenous eDNA from one or more relatively abundant and closely related taxa is amplified due to sequence complementarity with assay primers, but not detected due to mismatches with the hydrolysis probe sequence (Kainz 2000).

Improved understanding of the fundamental, functional, and quantitative effects of PCR inhibition on eDNA surveys has the potential to greatly improve survey planning, data interpretation, and model generation. Our aim is to contribute to this understanding by experimentally characterizing the interplay between several known or suspected inhibitors with a suite of different qPCR assays designed to detect macrobial aquatic species. In this case, we focused on several different inhibitors that might be expected to occur in environmental water samples and on qPCR assays designed to detect silver carp (Hypophthalmichthys molitrix) and bighead carp (Hypophthalmichthys nobilis). These two species have established invasive populations in many areas of the world and have been the subject of considerable eDNA development and study (e.g., Jerde et al. 2011; Turner et al. 2014; Klymus et al. 2015).

\section{Materials and methods}

\section{Inhibitors and inhibitor preparations}

The effects on qPCR of two different general classes of PCR inhibitors that may be co-extracted in aquatic eDNA samples were investigated: (i) compounds derived from plants and (ii) high concentrations of exogenous DNA. In the case of compounds derived from plants, we initially tested the inhibitory effects of discrete compounds that may be released from decaying organic matter, particularly plant material, in water bodies, namely humic acid, phytic acid, and tannic acid. We further tested the inhibition of qPCR by crude extracts from red maple (Acer rubrum) and black willow (Salix nigra) leaves. We selected these two species because they are local (Vicksburg, Mississippi, USA) representatives of tree genera that are typically abundant along river bottomlands where invasive populations of Hypophthalmichthys are found in North America and are thus representative of species that likely contribute decaying leaf biomass, and associated inhibitory substances, into those aquatic systems. In the case of high-concentration DNA, we further explore the influence of DNA sequence similarity on PCR inhibition by investigating DNA from three sources of differing evolutionary distance from Hypophthalmichthys (closest to most distant; refer to online Supplementary Material, Table S11): golden shiner (Notemigonus crysoleucas), salmon (Salmonidae), and the bacterium Escherichia coli. Golden shiners are confamilial (Cyprinidae) with Hypophthalmichthys. The effects of increasing concentrations of inhibitors on qPCR were measured as declines in the estimated copy number of template DNA (concentration remained constant), which we term, for the purposes of this study, as "declines in sensitivity". This approach to quantifying the effects of inhibitors on qPCR assays of eDNA samples differs somewhat from the common usage of $\Delta \mathrm{Cq}$ (i.e., change in quantification cycle) as a measure of inhibition (Jane et al. 2015; Goldberg et al. 2016). Nor do we use the common criterion of $\Delta \mathrm{Cq}=3$ as a threshold for considering a sample as "inhibited" (Turner et al. 2015; Goldberg et al. 2016). There is currently no standard criterion among eDNA studies for describing levels of inhibition, and we believed that expressing inhibition as changes in estimated copy number would be both sufficient for those readers with qPCR expertise and more meaningful to those readers lacking such expertise.

Humic acid sodium salt (Sigma-Aldrich, USA; product No. H16752), phytic acid sodium salt hydrate (Sigma-Aldrich; product No. P8810; $\mathrm{C}_{6} \mathrm{H}_{18} \mathrm{O}_{24} \mathrm{P}_{6}$ ), and tannic acid powder (Sigma-Aldrich; product No. 403040; $\mathrm{C}_{76} \mathrm{H}_{52} \mathrm{O}_{46}$ ) were each serially diluted and incorporated into $20 \mu \mathrm{L}$ qPCR solutions to test the effects of changing inhibitor concentrations on different qPCR assays. Fresh maple and willow leaves were collected locally and air-dried for 2 weeks at room temperature, after which $10 \mathrm{~g}$ of dried leaf material were boiled in $2 \mathrm{~L}$ of pure water for $1 \mathrm{~h}$ with agitation. A coloured aqueous solution resulted - presumably containing qPCR inhibitors and was then serially diluted as described in Table 1 and then included as $1 \mu \mathrm{L}$ aliquots in $20 \mu \mathrm{L}$ qPCRs to test the effects of changes in these inhibitor concentrations (0.0004-0.05x dilution relative to original leaf solution; Table 1) on the different qPCR assays. An additional test of even more concentrated leaf solutions was conducted by drying $1,5,25$, and $50 \mu \mathrm{L}$ of original undiluted solutions in the wells of 384-well plates and then running qPCR assays in those wells (i.e., $0.25 \times$ dilution, $1.25 \times$ concentration, and $2.5 \times$ concentration relative to the original leaf solution; Table 1).

Total genomic DNA (gDNA) was extracted from golden shiner tissues using the DNeasy Blood and Tissue Kit (Qiagen, USA) using a NanoDrop 1000 spectrophotometer (Thermo Fisher Scientific, USA). A dilution series (Table 1) with nine concentration classes was then generated. A $10 \mathrm{mg} \cdot \mathrm{mL}^{-1}$ pure stock of salmon sperm DNA was purchased from Life Technologies (Life Technologies; product No. 15632011), and a dilution series (Table 1) with eight concentration classes was generated. Whole gDNA from overnight culture of E. coli strain K12 ER2738 (New England Biolabs, 
Table 1. PCR inhibitors used in tests of several Hypophthalmichthys molitrix and Hypophthalmichthys nobilis eDNA markers, with details on tested concentrations (within $20 \mu \mathrm{L}$ qPCR solutions).

\begin{tabular}{lll}
\hline & \multicolumn{2}{l}{ Dilution and concentration series } \\
\cline { 2 - 3 } Inhibitor & Unit & Concentration \\
\hline Humic acid & $\mathrm{ng} \cdot \mu \mathrm{L}^{-1}$ & $250,125,50,25,5,2.5,0.5$ \\
Phytic acid & $\mathrm{ng} \cdot \mu \mathrm{L}^{-1}$ & $2500,1000,500,250,50,12.5,2.5,0.5$ \\
Tannic acid & $\mathrm{ng} \cdot \mu \mathrm{L}^{-1}$ & $750,500,250,125,50,12.5,2.5,0.5$ \\
Red maple & $X$ & $2.5,1.25,0.25,0.05,0.01,0.002,0.0004$ \\
Black willow & $X$ & $2.5,1.25,0.25,0.05,0.01,0.002,0.0004$ \\
Golden shiner & $\mathrm{ng} \cdot \mu \mathrm{L}^{-1}$ & $900,600,300,100,47.5,31,16.8,8.4,4.2$ \\
$\quad$ DNA & & \\
Salmon DNA & $\mathrm{ng} \cdot \mu \mathrm{L}^{-1}$ & $1500,1000,500,250,125,50,25,5$ \\
E. coli DNA & $\mathrm{ng} \cdot \mu \mathrm{L}^{-1}$ & $3250,1625,975,530,265,115,50,25$ \\
\hline
\end{tabular}

Note: $X=$ multiplier for change in concentration of leaf extract in qPCR solution relative to original solution.

Inc., Ipswich, Massachusetts, USA) was extracted using the DNeasy Blood and Tissue Kit and quantified using the Nanodrop 1000. A dilution series of the E. coli DNA (Table 1) with eight concentration classes was then generated.

All dilutions of the inhibitors were carried out using Ambion nuclease-free purified water (Thermo Fischer Scientific, USA). All inhibitor dilution series used in these trials were based on preliminary range-finding tests that identified the minimum compound concentrations at which qPCR assays were completely inhibited (data not shown). The tested levels of humic, phytic, and tannic acids, which are all classes of dissolved organic carbon (DOC), were very high (about $10^{0}-10^{3} \times$ ) compared with some of the highest published DOC concentrations (Sobek et al. 2007; Osburn et al. 2011; Mostofa et al. 2013). We assume that these high concentrations were, in large part, required due to our use of Environmental Master Mix 2.0 (Life Technologies) for all assays. Environmental Master Mix 2.0 is well known to provide robust qPCR results in the presence of inhibitors (Jane et al. 2015; Verhaegen et al. 2016) and is likely the most commonly used component in eDNA assays that utilize hydrolysis probe qPCR (e.g., TaqMan qPCR; Turner et al. 2014; Jane et al. 2015; Sigsgaard et al. 2015). As hydrolysis probe qPCR is the recommended (Goldberg et al. 2016) and, likely, most common PCR method utilized for eDNA surveys, and as even qPCRs utilizing Environmental Master Mix 2.0 can be inhibited (Doi et al. 2015; Sigsgaard et al. 2015; Turner et al. 2015), our results are particularly relevant to current eDNA practice. We would also surmise that inhibition may be a function of multiple co-acting substances, which may each individually contribute to inhibition while occurring at lower concentrations than we had to use for our trials. We also note that the concentrations of exogenous DNA used in our inhibition trials are very high (about $10^{1}-10^{4} \times$ ) compared with DNA concentrations typically found in total DNA extracts from water samples (Deiner et al. 2015; Djurhuus et al. 2017; Shahraki et al. 2019), and even about 3-10x the concentrations that might be expected from a typical PCR yield. In any case, a primary focus of this study was to explore a general trend in how different qPCR assays interact with the same inhibitors, not to detail precise quantitative relationships between particular assays and different inhibitory substances. A key objective then was to simply achieve qPCR inhibition, regardless of the concentrations of inhibitors required to achieve it.

\section{Hypophthalmichthys eDNA assays and qPCRs}

Several published qPCR assays designed for detecting Hypophthalmichthys carps were used to test how the effects of inhibitors might vary among different assays (Farrington et al. 2015). Descriptive metrics (Table 2; Table $S 1^{1}$ in the Supplementary Material) for each assay and its associated amplicon were determined using Geneious R8 (Biomatters, New Zealand). Commercial synthesized G-block fragments (IDT, USA) matching the qPCR ampli-
Table 2. The qPCR markers (i.e., primers and probes) for bighead carp (BHC) and silver carp (SC) that were used to characterize the effects of different PCR inhibitors on qPCR.

\begin{tabular}{llllrll}
\hline Marker & $\begin{array}{lllrl}\text { Target } \\
\text { species }\end{array}$ & $\begin{array}{l}\text { Primer and } \\
\text { probe GC\% }\end{array}$ & Tm & $\begin{array}{r}\text { Amp } \\
\text { BP }\end{array}$ & $\begin{array}{l}\text { Amp } \\
\text { GC\% }\end{array}$ & $\begin{array}{l}\text { Amp } \\
\text { Tm }\end{array}$ \\
\hline SC-TM4 & SC & 50.0 & 56.1 & 169 & 46.2 & 79.8 \\
SC-TM5 & SC & 47.6 & 58.3 & 99 & 43.4 & 75.9 \\
BH-TM1 & BHC & 46.6 & 56.4 & 145 & 44.1 & 78.4 \\
BH-TM2 & BHC & 50.0 & 60.2 & 97 & 45.0 & 77.0 \\
AC-TM1 & Both & 46.7 & 60.2 & 146 & 47.3 & 79.7 \\
AC-TM3 & Both & 46.8 & 56.6 & 134 & 45.5 & 78.5 \\
\hline
\end{tabular}

Note: Primer and probe GC\% details the mean percent GC nucleotide content of the forward primer, reverse primer, and hydrolysis probe. Tm and Amp Tm detail the melting temperatures $\left({ }^{\circ} \mathrm{C}\right)$ of the primer-probe set (mean value) and resulting amplicon, respectively. Amp BP and Amp GC\% detail the length (in DNA base pairs) and percent GC nucleotide content, respectively, of the resulting amplicons. Amplicon statistics are based on National Center for Biotechnology Information GenBank (Benson et al. 2013) DNA sequence accessions KR756343.1 and KJ729076.1 are for BHC and SC, respectively.

con sequences were used as DNA templates. A ViiA 7 Real-Time PCR System (Thermo Fisher Scientific) was used for all qPCR trials. The qPCR assays were multiplexed in the following pairs: BH-TM1 and BH-TM2; SC-TM4 and SC-TM5; and AC-TM1 and AC-TM3 (Table 2). Within each multiplex, one primer set would bear the fluorescent reporter dye 6FAM and the other would bear the fluorescent reporter dye VIC (Life Technologies). Farrington et al. (2015) found no substantial decline in assay sensitivity when these assays were used in multiplex. Additionally, these multiplex qPCRs provide insight into eDNA assays that are multiplexed with IPCs. All qPCR reactions contained $10 \mu \mathrm{L}$ of $2 \times$ TaqMan Environmental Master Mix 2.0, $0.5 \mu \mathrm{mol} \cdot \mathrm{L}^{-1}$ of each primer, $0.125 \mu \mathrm{mol} \cdot \mathrm{L}^{-1}$ of probe, $1 \mu \mathrm{L}$ of DNA template (1000 copies $\left.\mu \mathrm{L}^{-1}\right), 1 \mu \mathrm{L}$ of select inhibitor solution (except trials with dried-down leaf extract already in PCR plate wells), and ultrapure water to a final volume of $20 \mu \mathrm{L}$. DNA template concentrations were calculated based on manufacturerprovided stock concentrations and subsequent dilution factors. Thermal-cycling profiles for the qPCR tests were as follows: temperature cycling began with an initial denaturation step at $95{ }^{\circ} \mathrm{C}$ for $10 \mathrm{~min}$, followed by 40 cycles of $95{ }^{\circ} \mathrm{C}$ for $15 \mathrm{~s}$ and $60{ }^{\circ} \mathrm{C}$ for $1 \mathrm{~min}$. Four replicate qPCRs were run for each combination of assay, inhibitor, and inhibitor concentration. A minimum of four negative controls (water blanks) and at least eight positive controls (no added inhibitor) were run for each assay. Positive controls were run to provide a robust baseline for expected copy number estimates in uninhibited qPCRs. Sixfold $5 \times$ dilution series (10-31250 copies $\mu \mathrm{L}^{-1}$ ) of each G-block DNA template were used as quantitation standards. Finally, four no-template qPCRs containing inhibitors, at all tested concentrations, were run for each type of inhibitor to determine whether inhibitory substances caused any changes to background fluorescence.

\section{Statistical analysis}

For quality control purposes, any qPCR demonstrating a threshold cycle (Ct) outside of the first standard deviation of the mean $\mathrm{Ct}$ for the four replicate reactions for each trial (inhibitor concentration + assay) was eliminated from the data set. For each type of inhibitor, the distribution of qPCR estimates of DNA copy number (CN) were plotted against increasing inhibitor concentrations. The differences in how assays responded to various concentrations of inhibitor were assessed using an analysis of variance (ANOVA) model with $\log (\mathrm{CN})$ as a function of inhibitor concentration and assay, with interaction effects between inhibitor concentration and assay included in the model. $\mathrm{CN}$ values of 0 were adjusted to minimal nonzero values (e.g., 0.0001) to linearize data using a $\log (10)$ transformation. The potential influence of the fluorescent qPCR reporter dyes (6Fam, Vic; Thermo Fisher Scientific; Table $S 1^{1}$ ) as co-factors in our results were likewise assessed using ANOVA, 
Fig. 1. The effects of increasing concentrations of humic acid on qPCR estimates of original DNA template copy number (CN; calculated at 1000 copies across all treatments). Lines represent trends in mean estimated $\mathrm{CN}$ for each marker.

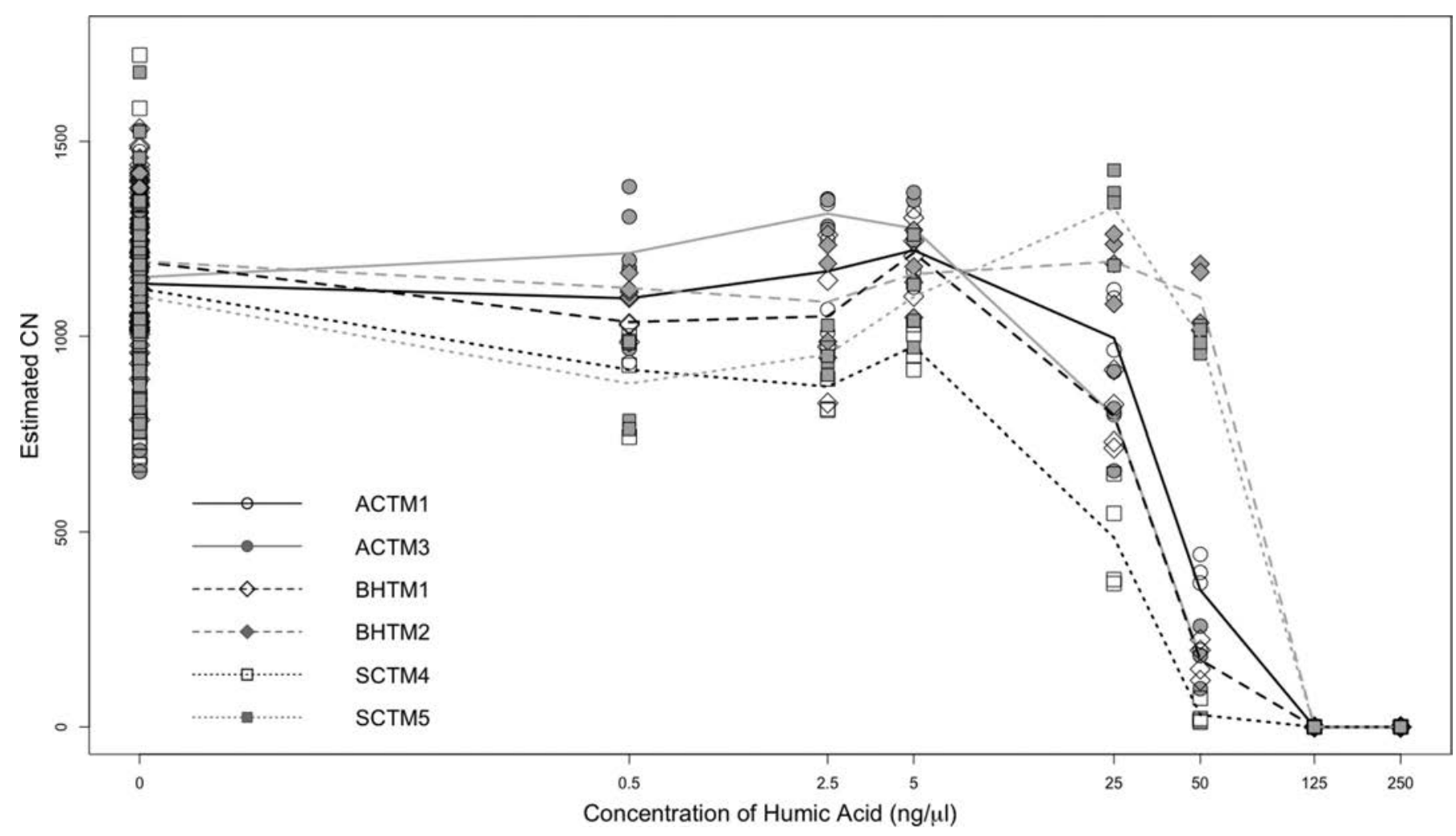

Fig. 2. The effects of increasing concentrations of phytic acid on qPCR estimates of original DNA template copy number (CN; calculated at 1000 copies across all treatments). Lines represent trends in mean estimated $\mathrm{CN}$ for each marker.

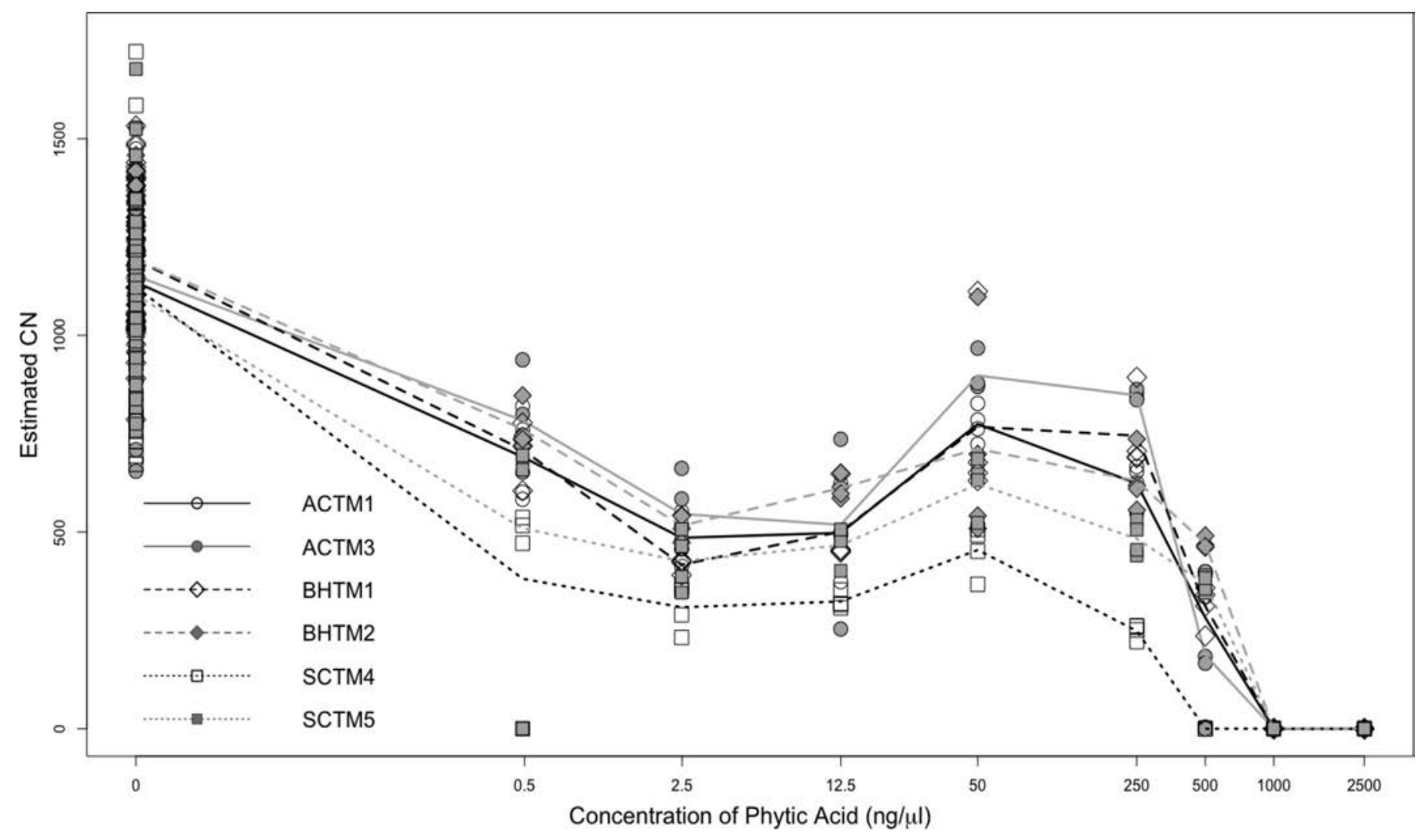


Fig. 3. The effects of increasing concentrations of tannic acid on qPCR estimates of original DNA template copy number (CN; calculated at 1000 copies across all treatments). Lines represent trends in mean estimated $\mathrm{CN}$ for each marker.

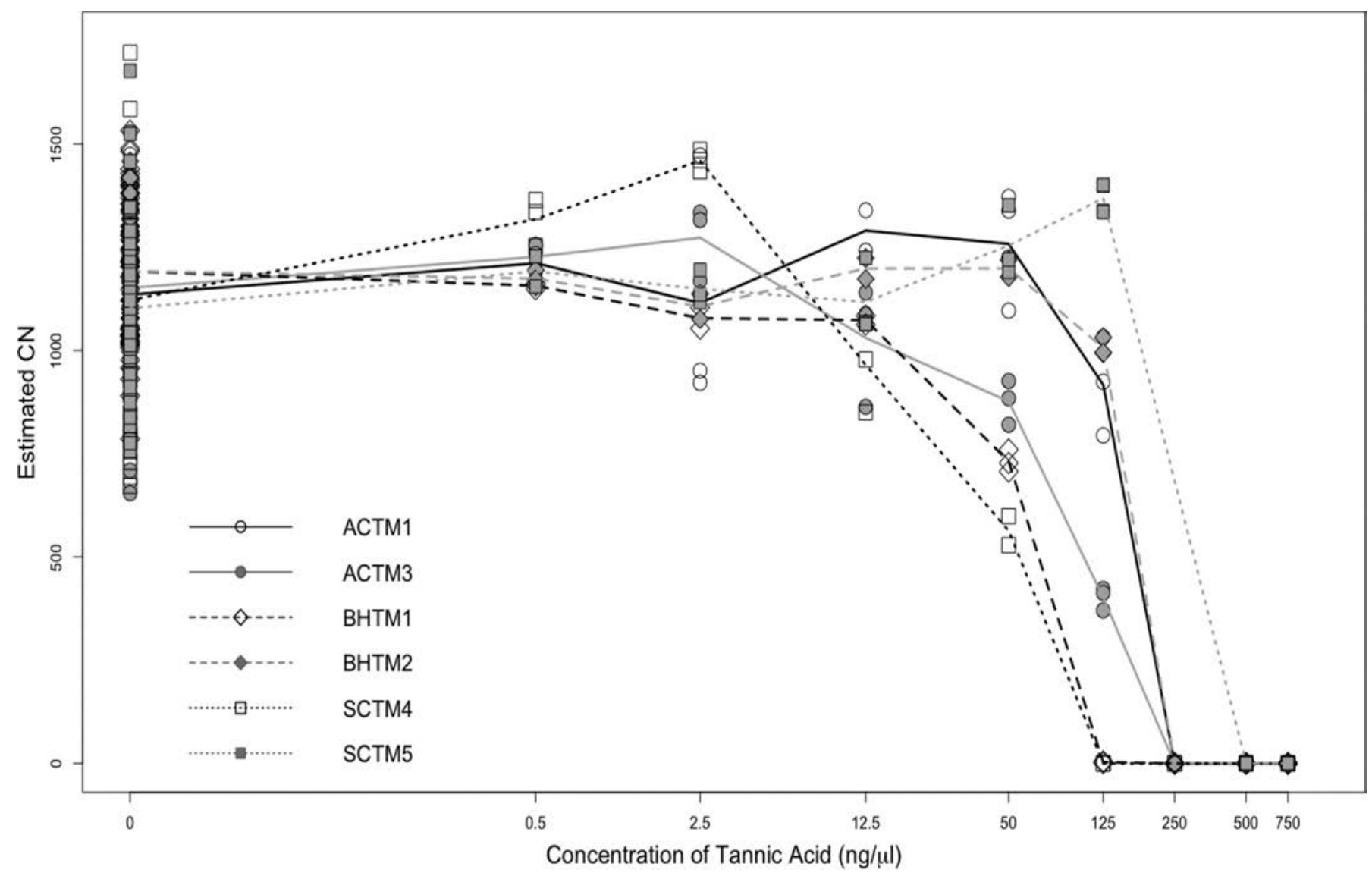

with $\log (\mathrm{CN})$ as a function of inhibitor concentration and dye, with interaction effects between inhibitor concentration and dye included in the model. For each inhibitor we explored the influence of primer-probe attributes (\%GC content, melting temperature; Table 2) on inhibition using analyses of covariance (ANCOVAs), where the regression coefficient determined earlier for each assay in the preceding ANOVAs comprised the dependent variable. Similar analyses were conducted for amplicon attributes (length, \%GC content, melting temperature; Table 2) as well. All statistical analyses were conducted using $\mathrm{R}$ version 3.4.3 (R. Core Team 2017).

\section{Results}

Inhibitors by themselves did not induce any detectable change in background fluorescence levels in any qPCR assay conducted during the study.

\section{Humic, phytic, and tannic acids}

Humic acid, phytic acid, and tannic acid all inhibited qPCR at some concentration (Figs. 1-3), but patterns of inhibition differed considerably among inhibitors and to some degree among qPCR assays. Clear inhibition of qPCR, where at least some mean CN estimates were significantly lower than those of control reactions, was observed at $50 \mathrm{ng} \cdot \mu \mathrm{L}^{-1}$ with humic acid, at $500 \mathrm{ng} \cdot \mu \mathrm{L}^{-1}$ with phytic acid, and at $250 \mathrm{ng} \cdot \mu \mathrm{L}^{-1}$ with tannic acid (Figs. 1-3). With humic acid (Fig. 1), qPCR sensitivity appeared to be unaffected over several dilution classes and then rapidly dropped for some assays at a concentration of $50 \mathrm{ng} \cdot \mu \mathrm{L}^{-1}$, with absolute inhibition of all qPCR assays observed at $125 \mathrm{ng} \cdot \mu \mathrm{L}^{-1}$. With phytic acid (Fig. 2), there was an immediate increase in inhibition (decline in estimated $\mathrm{CN}$ ) at $0.5 \mathrm{ng} \cdot \mu \mathrm{L}^{-1}$, followed by a leveling off of inhibitor effect until absolute inhibition of all assays at between 500 and
$1000 \mathrm{ng} \cdot \mu \mathrm{L}^{-1}$. Tannic acid inhibition (Fig. 3) exhibited the most extreme pattern, with most assays having very rapid declines into absolute inhibition between 125 and $500 \mathrm{ng} \cdot \mu \mathrm{L}^{-1}$ tannic acid.

The decline in sensitivity with increasing concentrations of humic acid (Fig. 1) significantly fit an exponential decay curve $\left(R^{2}=\right.$ $0.867, p<0.001$ ) with no significant variance among assays, but a significant interaction between inhibitor concentration and assay ACTM3 $(p=0.015)$. The decline in sensitivity with increasing concentrations of phytic acid (Fig. 2) also significantly fit an exponential decay curve $\left(R^{2}=0.779, p<0.001\right)$ with no significant variance among assays nor any significant inhibitor concentration-assay interactions. The decline in sensitivity with increasing concentrations of tannic acid (Fig. 3) significantly fit an exponential decay curve $\left(R^{2}=0.799, p<0.001\right)$ with a significant variance among assays $(p=0.050)$, but no significant inhibitor concentration-assay interactions. Of note, SCTM4 was absolutely inhibited at lower concentrations than all other assays for all three inhibitors, with the exception of BHTM1 and tannic acid, for which both assays were absolutely inhibited at a lower concentration than other assays.

\section{Red maple and black willow extracts}

Extracts from the leaves of both red maple and black willow inhibited qPCR, but at different levels of dilution (Figs. 4-5). Inhibition with the maple leaf extract appeared to cause a more rapid decline from no observable effect to complete or nearly complete inhibition for all assays than was observed for the willow leaf extract. The decline in sensitivity with increasing concentrations of red maple leaf extract fit an exponential decay curve $\left(R^{2}=0.691\right.$, $p<0.001)$ with no significant variance among assays $(p=0.411)$ and no significant inhibitor concentration-assay interactions. The 
Fig. 4. The effects of increasing concentrations of maple leaf extract on qPCR estimates of original DNA template copy number (CN; calculated at 1000 copies across all treatments). Lines represent trends in mean estimated $\mathrm{CN}$ for each marker.

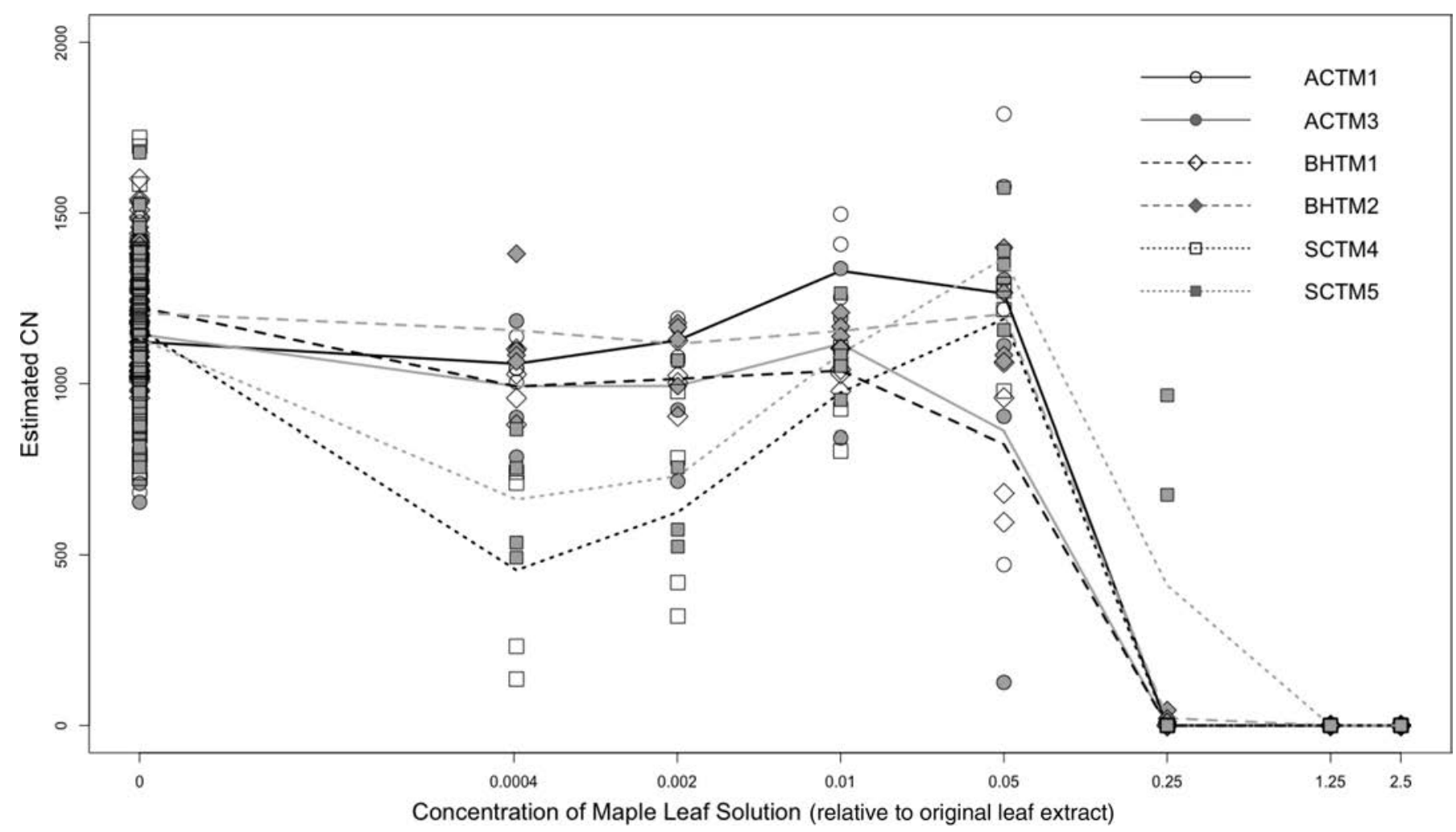

Fig. 5. The effects of increasing concentrations of willow leaf extract on qPCR estimates of original DNA template copy number (CN; calculated at 1000 copies across all treatments). Lines represent trends in mean estimated $\mathrm{CN}$ for each marker.

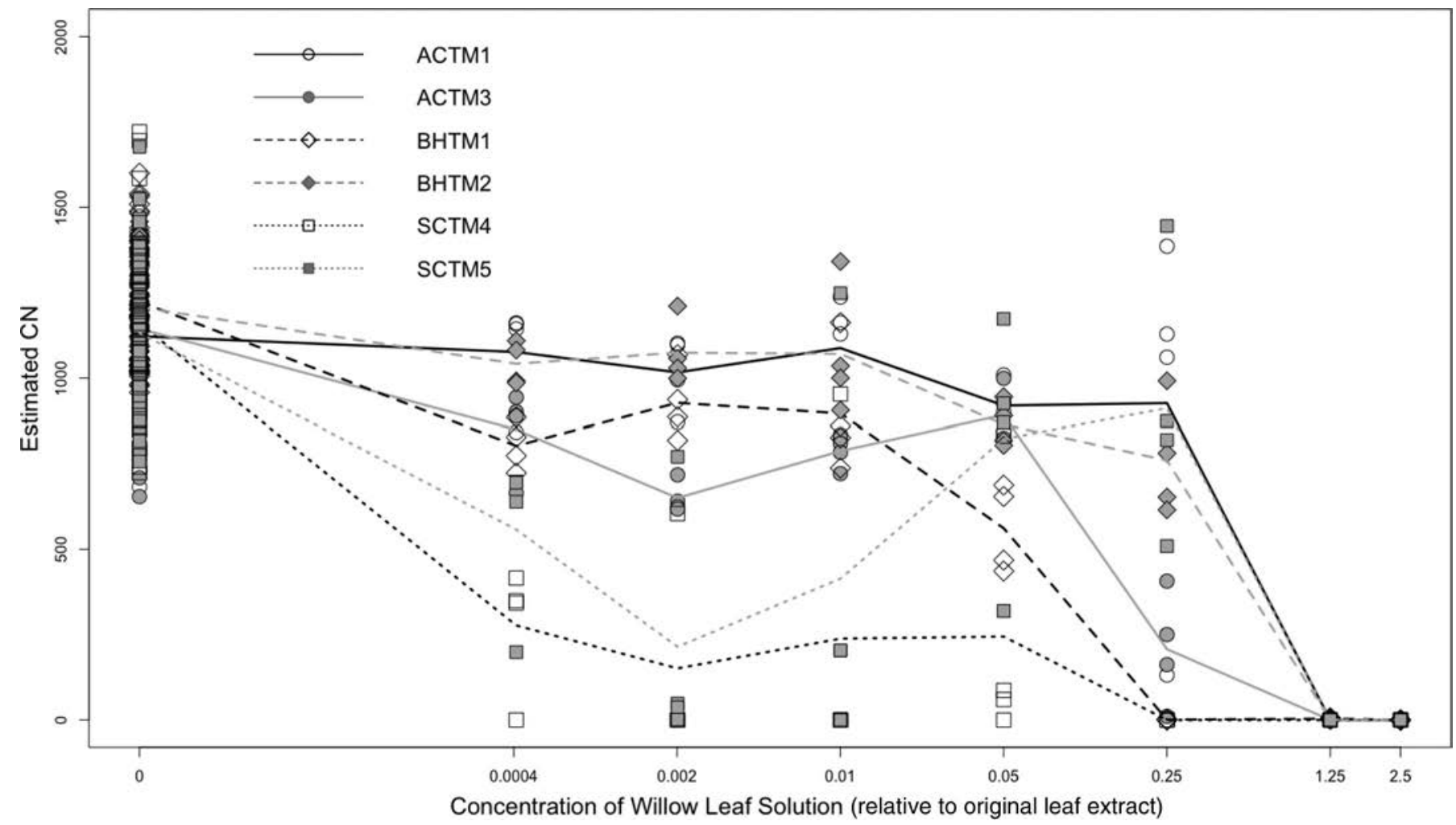


Fig. 6. The effects of increasing concentrations of golden shiner DNA on qPCR estimates of original DNA template copy number (CN; calculated at 1000 copies across all treatments). Lines represent trends in mean estimated $\mathrm{CN}$ for each marker.

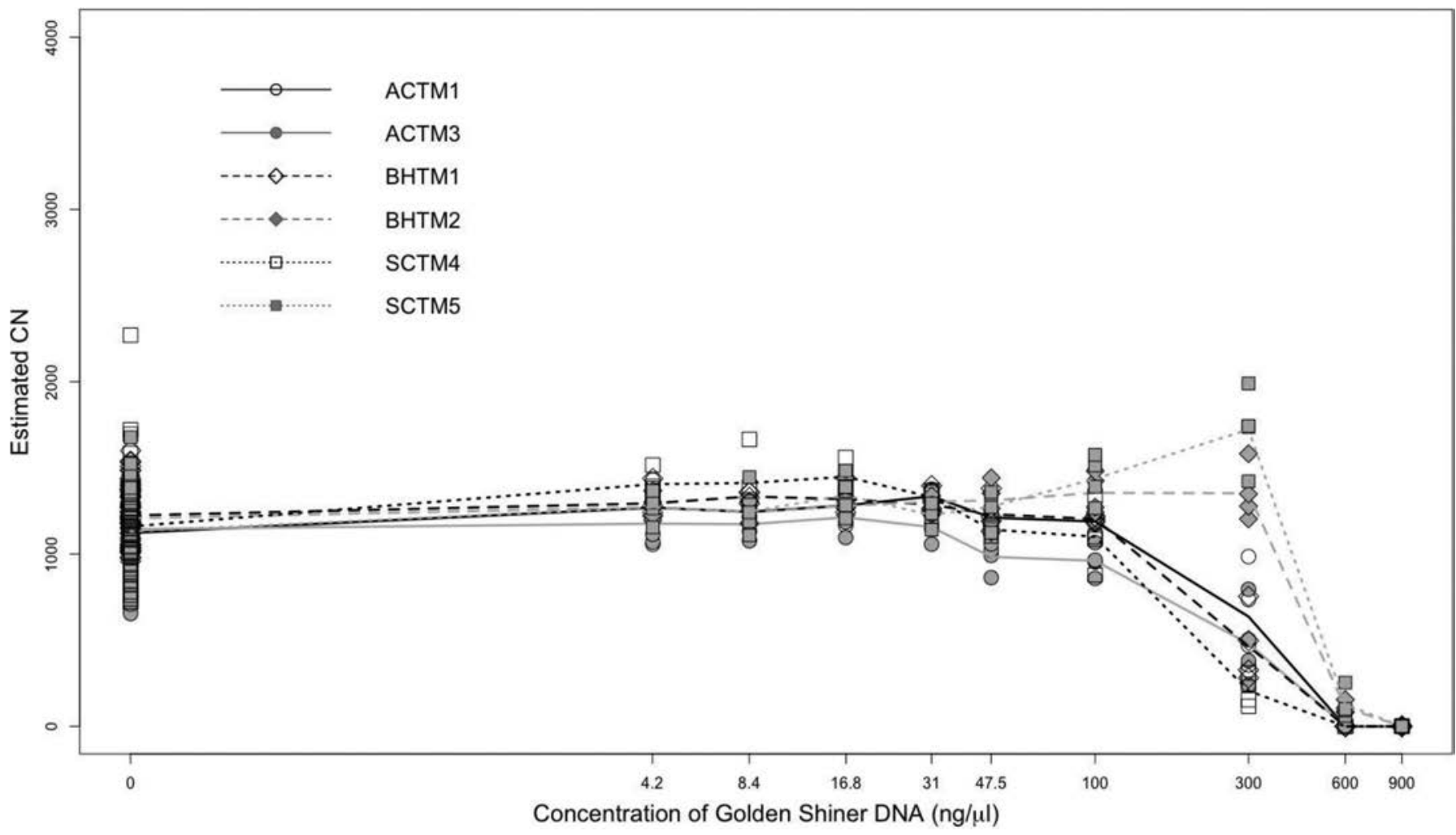

decline in sensitivity with increasing concentrations of willow leaf extract significantly fit an exponential decay curve $\left(R^{2}=\right.$ $0.659, p<0.001)$ with a significant variance among assays $(p<0.001)$, particularly SCTM4 $(p<0.001)$, but no significant inhibitor concentration-assay interactions. With the black willow trial, a significant variance was found between the two reporter dyes $(p=0.010)$, with 6FAM-labeled assays appearing to be more inhibited than VIC-labeled assays (Fig. S11ㅜ). There were no significant inhibitor concentration-dye interactions observed in this assay.

Golden shiner, salmon, and $E$. coli DNA

All three DNA types inhibited qPCR, with inhibition and absolute inhibition with golden shiner and salmon DNA (Figs. 6-7) occurring at much lower concentrations (largely by 600$1000 \mathrm{ng} \cdot \mu \mathrm{L}^{-1}$ ) than with E. coli DNA (at $\sim 3250 \mathrm{ng} \cdot \mu \mathrm{L}^{-1}$ or greater; Fig. 8). The decline in sensitivity with increasing concentrations of golden shiner gDNA significantly fit an exponential decay curve $\left(R^{2}=0.736, p<0.001\right)$ with a significant variance among assays $(p=0.025)$ and significant interactions effects for inhibitor concentration and assays $(p<0.001)$, including with BHTM2 $(p<0.001)$ and SCTM5 $(p<0.001)$. The decline in sensitivity with increasing concentrations of salmon sperm gDNA significantly fit an exponential decay curve $\left(R^{2}=0.596, p<0.001\right)$ with no significant variance among assays $(p=0.115)$ nor any significant interactions effects for inhibitor concentration and assays $(p=0.998)$. The decline in sensitivity with increasing concentrations of E. coli gDNA significantly fit an exponential decay curve $\left(R^{2}=0.707, p<0.001\right)$ with a significant variance among assays $(p<0.001)$, including BHTM1 $(p<0.001)$, BHTM2 $(p<0.001)$, and SCTM5 $(p<0.042)$. Significant interactions effects for inhibitor concentration and assays occurred with BHTM1 $(p<0.001)$, BHTM2 $(p<0.001)$, and SCTM5 $(p<0.001)$. In all three trials there were no significant dye effects $(p=0.217-0.814)$, but for each there were significant inhibitor concentration-dye interactions $(p<0.001)$. In all three cases,
6FAM-labeled assays were more inhibited at higher exogenous DNA concentrations than VIC-labeled assays (Fig. S2 ${ }^{1}$ ).

\section{Discussion}

In our study we found, not unexpectedly, that qPCR assays had a strong tendency for exponential decay in sensitivity to target DNA with increasing concentrations of different inhibitors. Interestingly, we found that the two different reporter dyes used for our assays seemed to influence apparent levels of inhibition when leaf extract from black willow was applied to qPCR. This finding contrasts, to some degree, with Sidstedt et al. (2015), who found that though humic substances inhibited qPCRs, the tested humics did not actually impact the fluorescent properties of the hydrolysisprobe dye. It may be that the willow leaf extract we prepared contained particular compounds that act to quench 6FAM to a greater degree than VIC. The lack of any significant effect of red maple extract on reporter dyes, along with similar lack of effect from the other organic carbon inhibitors (humic, tannic, and phytic acids), reinforces the observation that inhibitor effects on qPCR-based eDNA assays are complex and difficult to anticipate.

High concentrations of exogenous DNA proved to be inhibitory to qPCR assays, though at concentrations that may be rarely, if ever, encountered with eDNA samples. This inhibition is likely a function of PCR constituent saturation similar to what occurs with PCR amplification plateaus (Kainz 2000). The observation that qPCR assays were inhibited to different degrees at different concentrations of fish and E. coli DNA indicates that sequence similarity (Table $\mathrm{S}^{1}$ ) can play a role in exogenous DNA inhibition of PCR. Given this observation, it is clear that the development of assays that not only do not fluoresce but also do not amplify DNA from related taxa that co-occur with target taxa, especially if these nontarget taxa are more abundant, should be a critical concern. We further note that, contrary to our expectation, we did not observe a clear difference between inhibition levels resulting from 
Fig. 7. The effects of increasing concentrations of salmon DNA on qPCR estimates of original DNA template copy number (CN; calculated at 1000 copies across all treatments). Lines represent trends in mean estimated $\mathrm{CN}$ for each marker.

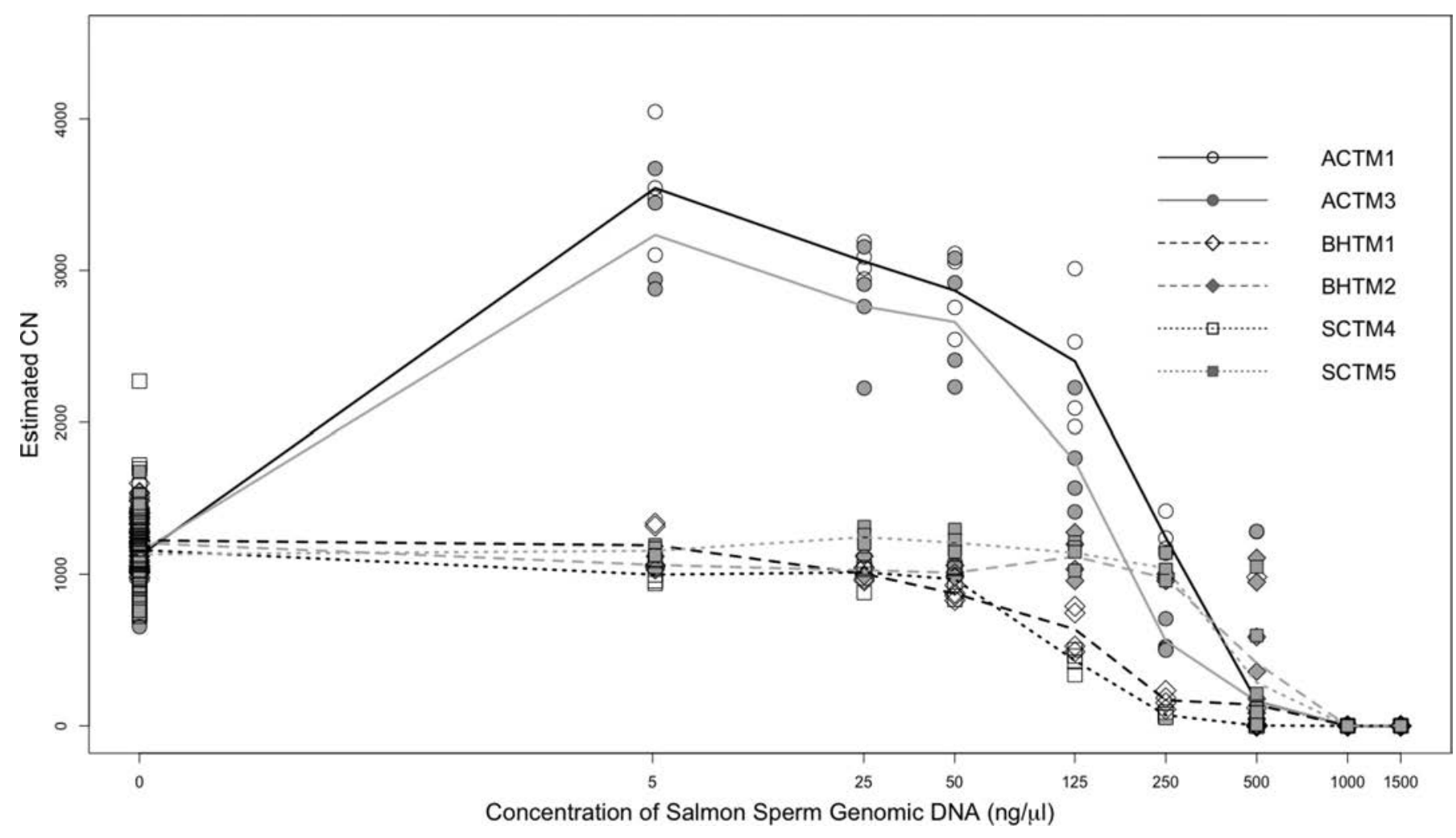

Fig. 8. The effects of increasing concentrations of E. coli DNA on qPCR estimates of original DNA template copy number (CN; calculated at 1000 copies across all treatments). Lines represent trends in mean estimated $\mathrm{CN}$ for each marker.

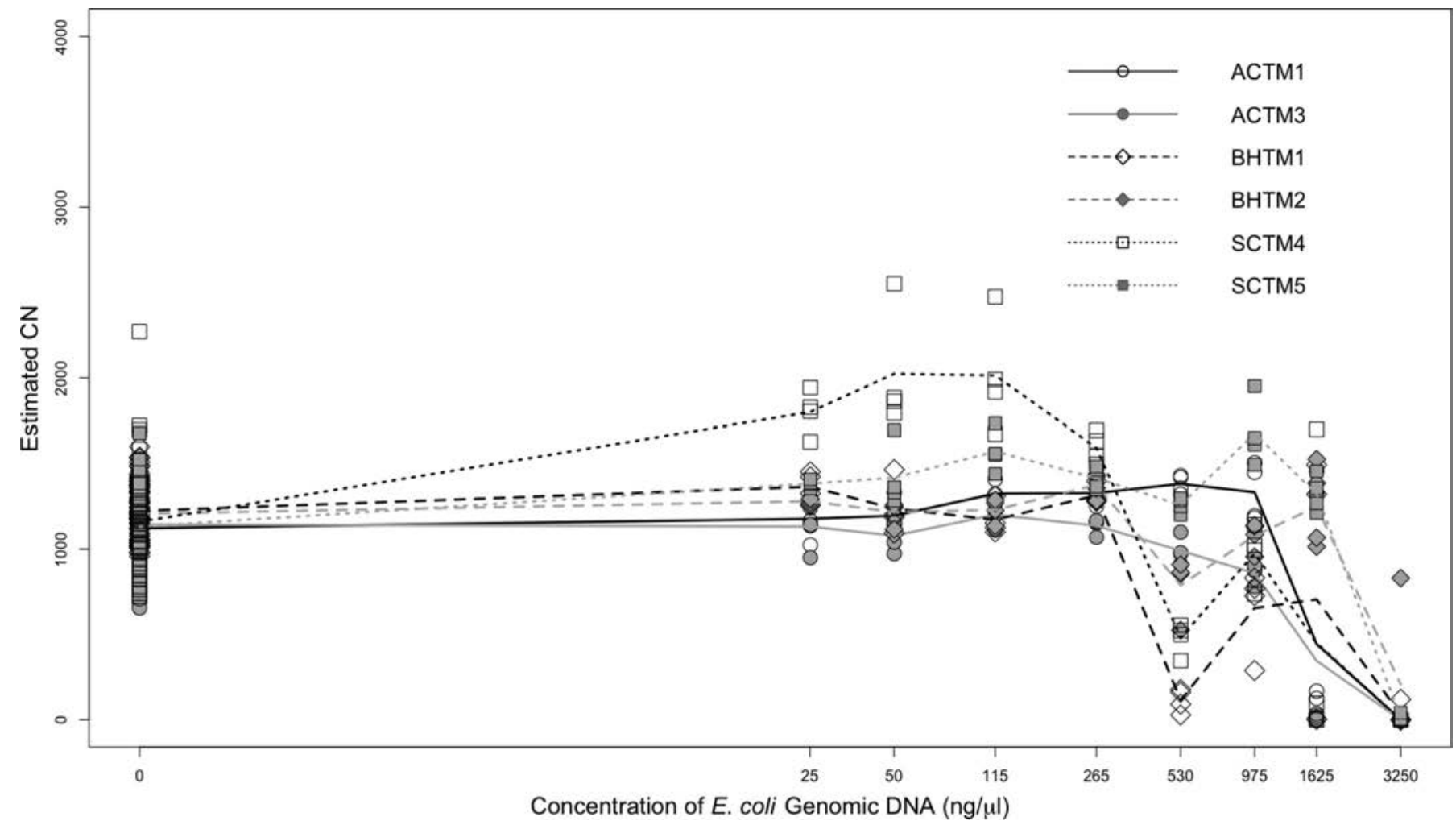


high concentrations of golden shiner and salmon DNA (Figs. 6-7). It may be that sequence mismatch levels between golden shiner and salmon DNA at loci homologous to bighead carp eDNA assays (i.e., primers and probes) were small enough that high concentrations of gDNA from the two species had similar inhibitory effects on those bighead carp assays. In any case, the degree of phylogenetic relatedness that must be considered when designing new assays may have to reach beyond the level of genera and families. We observed such a phenomenon during the design and testing of conventional, endpoint PCR assays for bighead carp, silver carp, and the black carp (Mylopharyngodon piceus; R. Lance and X. Guan, personal observation). Also of note, based on the inhibition of our assays by E. coli gDNA, even temporary binding interactions between qPCR oligonucleotides (i.e., primers and probes) and exogenous DNA template with which PCR primers have poor complementarity can reduce the rate at which assay oligonucleotides bind to target loci (Kainz 2000). We also found that inhibition resulting from high exogenous DNA concentrations was influenced by DNA concentration-reporter dye interactions. We do not know why this effect emerged in our trials, but, again, such observations reflect the challenge of conducting molecular-level analyses on complex environmental samples. In any case, considering the very high levels of exogenous DNA required, as a single factor, to bring about detectable qPCR inhibition in our trials, it may be that exogenous DNA either only functions as co-factor in eDNA assay inhibition or is almost never an issue.

In terms of eDNA surveys, at a basic level, inhibitors can cause false negative results in eDNA surveys and result in misinformed management decisions. Models of the relationships between target organism presence (or abundance or biomass) and the probability of eDNA detection or eDNA copy number (e.g., Schmidt et al. 2013; Schultz and Lance 2015; Chambert et al. 2018) would also be confounded by inhibition. Currently, one way the problem of PCR inhibitors in eDNA samples is dealt with is by attempting to select DNA extraction-isolation kits and protocols that are comparatively more effective in removing inhibitory substances (Goldberg et al. 2015; McKee et al. 2015a; Eichmiller et al. 2016). However, the typically low and highly variable DNA yields obtained from environmental samples using most kits and protocols make it very difficult to surmise whether PCR suffers from inhibition or from little or no template DNA. Other approaches include either diluting DNA elutions in hopes that dilution of inhibitory substances will minimize their impacts on PCR or incorporating a second DNA clean-up (e.g., spin column purification) in an attempt to further minimize the concentration of inhibitors in the final DNA elution (Pilliod et al. 2013; McKee et al. 2015a; Eichmiller et al. 2016). However, as target eDNA tends to be a very scarce constituent of eDNA samples (there are often fewer than five copies of target DNA per microlitre of elution; R. Lance, personal observation), additional dilutions could result in qPCR aliquots lacking target DNA template and, thus, false negative results (McKee et al. 2015a). Additional cleaning steps also can lead to false negatives, as such steps nearly always fail to recover all the DNA - and often result in the loss of a majority of DNA - in the original elution (Sørensen et al. 2003; McKee et al. 2015a; R. Lance, personal observation). In some cases, inhibitor effects may be ameliorated using measures such as optimizing PCR component concentrations (e.g., $\mathrm{MgCl}_{2}$ ), amending PCR with compounds that can reduce inhibitor effects (e.g., bovine serum albumin; Dejean et al. 2012; Schmidt et al. 2013; Deiner et al. 2015), utilizing DNA polymerases that are more robust in the presence of inhibitors, etc. These PCR modifications, however, often do not completely ameliorate inhibitor effects, and their utility varies with the type of inhibitors present (Albers et al. 2013). Furthermore, water chemistries of systems from which eDNA samples are obtained typically are not characterized and samples may contain a mixture of different inhibitor classes.
A recurring pattern in our study was considerable variance in how different qPCR assays respond to the same inhibitor. Though not widely discussed in the eDNA literature, other studies have observed that different inhibitors impact eDNA assays in different ways (McKee et al. 2015a). Given the complexities in inhibitor constituencies that are likely to be found in environmental matrices (e.g., water, sediment), the variance in how different qPCR assays are affected is likely to be quite large. Under such conditions, if multiple assays targeting the same species are used in an eDNA survey, it may be that one or more assays are considerably inhibited, while other assay(s) may not be - providing detections that might otherwise be missed. This strategy, currently employed in eDNA monitoring for Hypophthalmichthys carps in the US (USFWS 2018), reduces the risk of false negative results due to qPCR inhibition. Multiple assays could be run either in a multiplex qPCR or in separate qPCRs.

To save on sample processing time and costs, and the losses of DNA, associated with additional sample treatments or sample dilution, researchers often incorporate IPCs into qPCR to identify those samples that are likely inhibited. Typically, a single qPCR IPC assay, either purchased from a commercial provider or designed in-house, is employed for some or all assays. A major implication arising from the observation that assays may vary considerably in how they are affected by inhibitors is that, in some cases, the expectation that qPCR eDNA assays and associated IPCs are responding to inhibitory factors in the same fashion, and that IPCs are providing useful information about assay inhibition, may be unfounded. For example, considering the apparently rapid shift from no significant inhibition to notable levels of inhibition for some inhibitor-assay combinations (Figs. 1-8), there will be situations where an IPC may show no notable inhibition, while the assay of interest is strongly inhibited and vice versa. This problematic issue had been noted previously in fields outside of eDNA. For example, Huggett et al. (2008) conducted a series of experiments demonstrating that different assays responded differently to inhibitors associated with human urine samples. These researchers noted, "If two different PCR reactions are to be compared, or one is to be used as a reference reaction for the other..., it is important that the two reactions are affected by potential inhibitors to the same extent." An IPC would be a clear instance of one assay being used as a "reference reaction for the other". Huggett et al. (2008) further coined a term, "inhibition compatibility", as a way of describing how well matched two or more assays are in their responses to the same inhibitor (and to the same concentrations of the same inhibitors). Until now, however, and to the best of our knowledge, the issue of inhibition compatibility, and its implications for IPCs, have not been explicitly addressed in the field of eDNA surveys and monitoring.

Huggett et al. (2008) also state, "Recognition of the importance of assessing inhibition compatibility should contribute to reducing error and increasing accuracy in both gene expression studies and PCR-based molecular diagnostics." Likewise, it seems important then that more effective IPC strategies be developed among eDNA practitioners. Methods for designing IPC assays that maximize inhibition compatibility between eDNA assays and IPCs will need to be devised. Our study results indicate that simply taking into account amplicon lengths, GC contents, and (or) primer, probe, and amplicon melting temperatures will be insufficient. These findings reflect those of Huggett et al. (2008), who also found no correlations between inhibition and several other primer and amplicon features (e.g., secondary structure). Likewise, common expectations for how IPCs are vetted and tested for use in eDNA surveys will need to emerge. If nothing else, it is advisable that eDNA studies utilizing IPCs compare the performances of IPCs and planned assays in the presence of some classes of inhibitors expected to be present in eDNA samples. In summary, the field of aquatic macrobial eDNA monitoring is rapidly evolving and becoming an increasingly important tool for ecologists. New ap- 
proaches for minimizing assay inhibition and for accounting for its effects on survey results will considerably advance the role of eDNA surveys in conservation and natural resources management.

\section{Acknowledgements}

We are grateful for a review of an earlier version of this manuscript provided by C. Jung and for M. Jung and N. Beane for help with leaf collection. We express thanks to the Government eDNA Working Group and our ERDC Environmental Processes Branch colleagues that provided much needed input on study design and data interpretation. Three anonymous reviewers provided comments and recommendations that were tremendously helpful. We are indebted to K. Baerwaldt for continued leadership and assistance with funding for eDNA research. This project was funded by the Great Lakes Restoration Initiative (GLRI), as administered by the United States Environmental Protection Agency, and overseen by the GLRI Asian Carp Coordinating Committee.

\section{References}

Albers, C.N., Jensen, A., Bælum, J., and Jacobsen, C.S. 2013. Inhibition of DNA

polymerases used in Q-PCR by structurally different soil-derived humic substances. Geomicrobiol. J. 30: 675-681. doi:10.1080/01490451.2012.758193.

Benson, D.A., Cavanaugh, M., Clark, K., Karsch-Mizrachi, I., Lipman, D.J., Ostell, J., and Sayers, E.W. 2013. GenBank. Nucleic Acids Res. 41: D36-D42. doi:10.1093/nar/gks1195. PMID:23193287.

Chambert, T., Pilliod, D.S., Goldberg, C.S., Doi, H., and Takahara, T. 2018. An analytical framework for estimating aquatic species density from environmental DNA. Ecol. Evol. 8: 3468-3477. doi:10.1002/ece3.3764. PMID:29607039.

Deiner, K., Walser, J., Mächler, E., and Altermatt, F. 2015. Choice of capture and extraction methods affect detection of freshwater biodiversity from environmental DNA. Biol. Conserv. 183: 53-63. doi:10.1016/j.biocon.2014.11.018.

Dejean, T., Valentini, A., Miquel, C., Taberlet, P., Bellemain, E., and Miaud, C. 2012. Improved detection of an alien invasive species through environmental DNA barcoding: The example of the American bullfrog Lithobates catesbeianus. J. Appl. Ecol. 49: 953-959. doi:10.1111/j.1365-2664.2012.02171.x.

Djurhuus, A., Port, J., Closek, C.J., Yamahara, K.M., Romero-Maraccini, O., Walz, K.R., et al. 2017. Evaluation of filtration and DNA extraction methods for environmental DNA biodiversity assessments across multiple trophic levels. Front. Mar. Sci. 4: 314. doi:10.3389/fmars.2017.00314.

Doi, H., Takahara, T., Minamoto, T., Matsuhashi, S., Uchii, K., and Yamanaka, H. 2015. Droplet digital polymerase chain reaction (PCR) outperforms real-time PCR in the detection of environmental DNA from an invasive fish species. Environ. Sci. Technol. 49: 5601-5608. doi:10.1021/acs.est.5b00253. PMID: 25850372.

Eichmiller, J.J., Miller, L.M., and Sorensen, P.W. 2016. Optimizing techniques to capture and extract environmental DNA for detection and quantification of fish. Mol. Ecol. Resour. 16: 56-68. doi:10.1111/1755-0998.12421. PMID:25919417.

Farrington, H.L., Edwards, C.E., Guan, X., Carr, M.R., Baerwaldt, K., and Lance, R.F. 2015. Mitochondrial genome sequencing and development of genetic assays for the detection of DNA of invasive bighead and silver carp (Hypophthalmichthys nobilis and $\mathrm{H}$. molitrix) in environmental water samples from the united states. PLoS ONE, 10(2): e0117803. doi:10.1371/journal.pone. 0117803. PMID:25706532.

Ficetola, G.F., Miaud, C., Pompanon, F., and Taberlet, P. 2008. Species detection using environmental DNA from water samples. Biol. Lett. 4(4): 423-425.

Fujiwara, A., Matsuhashi, S., Doi, H., Yamamoto, S., and Minamoto, T. 2016. Use of environmental DNA to survey the distribution of an invasive submerged plant in ponds. Freshw. Sci. 35: 748-754. doi:10.1086/685882.

Goldberg, C.S., Pilliod, D.S., Arkle, R.S., and Waits, L.P. 2011. Molecular detection of vertebrates in stream water: A demonstration using rocky mountain tailed frogs and Idaho giant salamanders. PLoS ONE, 6: e22746. doi:10.1371/journal. pone.0022746. PMID:21818382.

Goldberg, C.S., Strickler, K.M., and Pilliod, D.S. 2015. Moving environmental DNA methods from concept to practice for monitoring aquatic macroorganisms. Biol. Conserv. 183: 1-3. doi:10.1016/j.biocon.2014.11.040.

Goldberg, C.S., Turner, C.R., Deiner, K., Klymus, K.E., Thomsen, P.F., Murphy, M.A., et al. 2016. Critical considerations for the application of environmental DNA methods to detect aquatic species. Methods Ecol. Evol. 7: 1299-1307. doi:10.1111/2041-210X.12595.

Goring, C., and Bartholomew, W.V. 1952. Adsorption of mononucleotides, nu- cleic acids, and nucleoproteins by clays. Soil Sci. 74(2): 149-164. doi:10.1097| 00010694-195208000-00005.

Huggett, J.F., Novak, T., Garson, J.A., Green, C., Morris-Jones, S.D., Miller, R.F., and Zumla, A. 2008. Differential susceptibility of PCR reactions to inhibitors: An important and unrecognised phenomenon. BMC Res. Notes, 1: 70. doi:10. 1186/1756-0500-1-70. PMID:18755023.

Jane, S.F., Wilcox, T.M., McKelvey, K.S., Young, M.K., Schwartz, M.K., Lowe, W.H., et al. 2015. Distance, flow and PCR inhibition: eDNA dynamics in two headwater streams. Mol. Ecol. Resour. 15: 216-227. doi:10.1111/1755-0998.12285. PMID:24890199.

Jerde, C.L., Mahon, A.R., Chadderton, W.L., and Lodge, D.M. 2011. "Sight-unseen" detection of rare aquatic species using environmental DNA. Conserv. Lett., 4(2): 150-157.

Kainz, P. 2000. The PCR plateau phase - towards an understanding of its limitations. Biochim. Biophys. Acta, 1494(1-2): 23-27. doi:10.1016/S0167-4781(00) 00200-1. PMID:11072065.

Klymus, K.E., Richter, C.A., Chapman, D.C., and Paukert, C. 2015. Quantification of eDNA shedding rates from invasive bighead carp Hypophthalmichthys nobilis and silver carp Hypophthalmichthys molitrix. Biol. Conserv. 183: 77-84. doi:10. 1016/j.biocon.2014.11.020.

McKee, A.M., Spear, S.F., and Pierson, T.W. 2015a. The effect of dilution and the use of a post-extraction nucleic acid purification column on the accuracy, precision, and inhibition of environmental DNA samples. Biol. Conserv. 183: 70-76. doi:10.1016/j.biocon.2014.11.031.

McKee, A.M., Calhoun, D.L., Barichivich, W.J., Spear, S.F., Goldberg, C.S., and Glenn, T.C. $2015 b$. Assessment of environmental DNA for detecting presence of imperiled aquatic amphibian species in isolated wetlands. J. Fish Wildl. Manag. 6(2): 498-510. doi:10.3996/042014-JFWM-034.

Mostofa, K.M., Liu, C., Mottaleb, M.A., Wan, G., Ogawa, H., Vione, D., et al. 2013. Dissolved organic matter in natural waters. In Photobiogeochemistry of organic matter. Edited by K.M.G. Mostofa, T. Yoshioka, A. Mottaleb, and D. Vione. Springer-Verlag, Berlin, DE. pp. 1-137.

Opel, K.L., Chung, D., and McCord, B.R. 2010. A study of PCR inhibition mechanisms using real time PCR. J. Forensic Sci. 55(1): 25-33. doi:10.1111/j.1556-4029. 2009.01245.x. PMID:20015162.

Osburn, C.L., Wigdahl, C.R., Fritz, S.C., and Saros, J.E. 2011. Dissolved organic matter composition and photoreactivity in prairie lakes of the U.S. Great Plains. Limnol. Oceanogr. 56(6): 2371-2390. doi:10.4319/lo.2011.56.6.2371.

Pilliod, D.S., Goldberg, C.S., Arkle, R.S., and Waits, L.P. 2013. Estimating occupancy and abundance of stream amphibians using environmental DNA from filtered water samples. Can. J. Fish. Aquat. Sci. 70(8): 1123-1130. doi:10.1139/ cjfas-2013-0047.

R Development Core Team. 2017. R: a language and environment for statistical computing. R Foundation for Statistical Computing, Vienna, Austria.

Schmidt, B.R., Kéry, M., Ursenbacher, S., Hyman, O.J., and Collins, J.P. 2013. Site occupancy models in the analysis of environmental DNA presence/absence surveys: A case study of an emerging amphibian pathogen. Methods Ecol. Evol. 4(7): 646-653. doi:10.1111/2041-210X.12052.

Schrader, C., Schielke, A., Ellerbroek, L., and Johne, R. 2012. PCR inhibitors occurrence, properties and removal. J. Appl. Microbiol. 113: 1014-1026. doi: 10.1111/j.1365-2672.2012.05384.x. PMID:22747964.

Schultz, M.T., and Lance, R.F. 2015. Modeling the sensitivity of field surveys for detection of environmental DNA (eDNA). PLoS ONE, 10: e0141503.

Shahraki, A.H., Chaganti, S.R., and Heath, D. 2019. Assessing high-throughput environmental DNA extraction methods for meta-barcode characterization of aquatic microbial communities. J. Water Health. 17(1): 37-49. doi:10.2166/ wh.2018.108.

Sidstedt, M., Jansson, L., Nilsson, E., Noppa, L., Forsman, M., Rådström, P., and Hedman, J. 2015. Humic substances cause fluorescence inhibition in realtime polymerase chain reaction. Anal. Biochem. 487: 30-37.

Sigsgaard, E.E., Carl, H., Møller, P.R., and Thomsen, P.F. 2015. Monitoring the near-extinct European weather loach in Denmark based on environmental DNA from water samples. Biol. Conserv. 183: 46-52. doi:10.1016/j.biocon.2014. 11.023

Sobek, S., Tranvik, L.J., Prairie, Y.T., Kortelainen, P., and Cole, J.J. 2007. Patterns and regulation of dissolved organic carbon: An analysis of 7,500 widely distributed lakes. Limnol. Oceanogr. 52(3): 1208-1219. doi:10.4319/1o.2007.52.3. 1208.

Sørensen, E., Hansen, S.H., Eriksen, B., and Morling, N. 2003. Applications of thiopropyl sepharose 6B for removal of PCR inhibitors from DNA extracts from different sources. Int. Congr. Ser. 1239: 821-823. doi:10.1016/S05315131(02)00523-X.

Stoeckle, B.C., Beggel, S., Cerwenka, A.F., Motivans, E., Kuehn, R., and Geist, J. 2017. A systematic approach to evaluate the influence of environmental conditions on eDNA detection success in aquatic ecosystems. PLoS ONE, 12: e0189119. doi:10.1371/journal.pone.0189119. PMID:29220394.

Sutlović, D., Definis-Gojanović, M., Anđelinović, Š., Gugić, D., and Primorac, D. 2005. Taq polymerase reverses inhibition of quantitative real time polymerase chain reaction by humic acid. Croat. Med. J. 46: 556-562.

Sutlović, D., Gamulin, S., Definis-Gojanovic, M., Gugic, D., and Andjelinovic, S. 2008. Interaction of humic acids with human DNA: Proposed mechanisms and kinetics. Electrophoresis, 29: 1467-1472.

Turner, C.R., Miller, D.J., Coyne, K.J., and Corush, J. 2014. Improved methods for 
capture, extraction, and quantitative assay of environmental DNA from Asian bigheaded carp (Hypophthalmichthys spp.). PLoS ONE, 9: e114329. doi:10. 1371/journal.pone.0114329. PMID:25474207.

Turner, C.R., Uy, K.L., and Everhart, R.C. 2015. Fish environmental DNA is more concentrated in aquatic sediments than surface water. Biol. Conserv. 183: 93-102. doi:10.1016/j.biocon.2014.11.017.

USFWS. 2018. Quality assurance project plan - eDNA monitoring of bighead and silver carps. United States Fish \& Wildlife Service, Bloomington, Minn.

Verhaegen, B., De Reu, K., De Zutter, L., Verstraete, K., Heyndrickx, M., and Van Coillie, E. 2016. Comparison of droplet digital PCR and qPCR for the quantification of shiga toxin-producing Escherichia coli in bovine feces. Toxins, 8(5): 157. doi:10.3390/toxins8050157.

Williams, K.E., Huyvaert, K.P., and Piaggio, A.J. 2017. Clearing muddied waters: Capture of environmental DNA from turbid waters. PLoS ONE, 12: e0179282. doi:10.1371/journal.pone.0179282. PMID:28686659.

Wilson, C., Wright, E., Bronnenhuber, J., MacDonald, F., Belore, M., Locke, B., et al. 2014. Tracking ghosts: combined electrofishing and environmental DNA surveillance efforts for Asian carps in Ontario waters of Lake Erie. Manag. Biol. Invasion, 5(3): 225-231. doi:10.3391/mbi.2014.5.3.05.

Wilson, I.G. 1997. Inhibition and facilitation of nucleic acid amplification. Appl. Environ. Microbiol. 63(10): 3741-3751. PMID:9327537. 


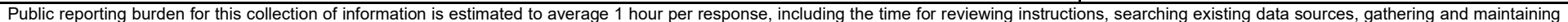

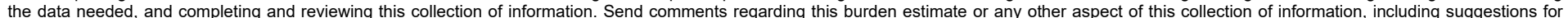

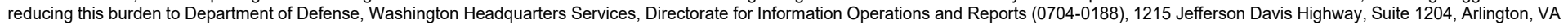

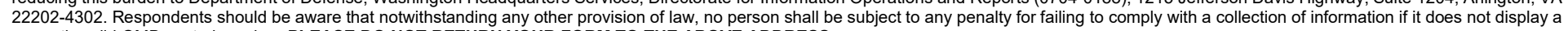
currently valid OMB control number. PLEASE DO NOT RETURN YOUR FORM TO THE ABOVE ADDRESS.
1. REPORT DATE (DD-MM-YYYY)
August 2021

4. TITLE AND SUBTITLEI

Variation in Inhibitor Effects on qPCR Assays and Implications for eDNA Surveys
3. DATES COVERED (From - To)

\section{5a. CONTRACT NUMBER}

5b. GRANT NUMBER

5c. PROGRAM ELEMENT NUMBER

5d. PROJECT NUMBER

5e. TASK NUMBER

5f. WORK UNIT NUMBER

8. PERFORMING ORGANIZATION REPORT NUMBER

ERDC/EL MP-21-9

Environmental Laboratory

U.S. Army Engineer Research and Development Center

3909 Halls Ferry Road

Vicksburg, MS 39180

9. SPONSORING / MONITORING AGENCY NAME(S) AND ADDRESS(ES)

U.S. Army Corps of Engineers

Washington, DC 20314
10. SPONSOR/MONITOR'S ACRONYM(S)

USACE

11. SPONSOR/MONITOR'S REPORT NUMBER(S)

\section{DISTRIBUTION / AVAILABILITY STATEMENT}

Approved for public release; distribution is unlimited.

13. SUPPLEMENTARY NOTES

This article was originally published in the Canadian Journal of Fish and Aquatic Science on 8 May 2019.

This project was funded by the Great Lakes Restoration Initiative (GLRI), as administered by the U.S. Environmental Protection Agency (EPA), and overseen by the GLRI Asian Carp Coordinating Committee.

\section{ABSTRACT}

Aquatic environmental DNA (eDNA) surveys are sometimes impacted by polymerase chain reaction (PCR) inhibitors. We tested varying concentrations of different inhibitors (humic, phytic, and tannic acids; crude leaf extracts) for impacts on quantitative PCR (qPCR) assays designed for eDNA surveys of bighead and silver carp (Hypophthalmichthys nobilis and Hypophthalmichthys molitrix). We also tested for inhibition by high concentrations of exogenous DNA, hypothesizing that DNA from increasingly closely related species would be increasingly inhibitory. All tested inhibitors impacted qPCR, though only at very high concentrations likely a function, in part, of having used an inhibitor-resistant qPCR solution. Closer phylogenetic relatedness resulted in inhibition at lower exogenous DNA concentrations, but not at relatively close phylogenetic scales. Inhibition was also influenced by the qPCR reporter dye used. Importantly, different qPCR assays responded differently to the same inhibitor concentrations. Implications of these results are that the inclusion of more than one assay for the same target taxa in an eDNA survey may be an important countermeasure against false negatives and that internal positive controls may not, in the absence of efforts to maximize inhibition compatibility, provide useful information about the inhibition of an eDNA assay.

\section{SUBJECT TERMS}

Microbial ecology, Molecular microbiology, Environmental monitoring, Polymerase chain reaction, Aquatic habitats, Bighead carp, Silver carp

16. SECURITY CLASSIFICATION OF:

\section{a. REPORT}

Unclassified b. ABSTRACT

Unclassified

\section{c. THIS PAGE}

Unclassified
17. LIMITATION OF ABSTRACT

UU
18. NUMBER OF PAGES

16 19a. NAME OF RESPONSIBLE PERSON

19b. TELEPHONE NUMBER (include area code) 